\title{
XLVI. On the origin and discovery of iron
}

\section{David Mushet Esq.}

To cite this article: David Mushet Esq. (1822) XLVI. On the origin and discovery of iron , Philosophical Magazine Series 1, 60:294, 249-253, DOI: 10.1080/14786442208652833

To link to this article: http://dx.doi.org/10.1080/14786442208652833

曲 Published online: 29 Jul 2009.

Submit your article to this journal 정

LII Article views: 4

Q View related articles $₫$ 
situate in the fire, that the materials operated upon may during the whole process be subjected to its greatest intensity.

With due attention to these precautions, and to some minor circumstances in the manipulation of the experiment, which I shall not take up the Society's time in detailing, it is believed that the decomposition of potash, by means of iron, might in every instance be effected with almost entire certainty, and potassium be obtained in great abundance.

\section{On the Origin and Discovery of Iron. By David Mushet, Esq.*}

[Continued from pagre $16 \%$ ]

However rude an instrument, in the hands of the early ironmaker, we may in our times consider the blast-bloomery to have been, yet there can be no doubt that in an operation so different from, and so much more complete than, the more ancient air-bloomery, many difficulties attended its general introduction. Prior to this, bellows must have been invented and in common use, and their construction substantial and well understood, before they were made powerful enongh to smelt ores of iron. It is also very probable that they were long used to forge the iron produced in the air-bloomery, before they were applied to the department of smelting.

Accident alone in almost every instance is the source or cause of invention. Anomalies in the arts and manufactures appear and vanish without notice or attention; and it is only when these fall under the observation of persons of investigating habits, that they are ever philosophically accounted for, or made subservient to useful or beneficial purposes. Bellows, in the first instance, were likely applied in the bloomery upon any occasional diminution of the usual or necessary current of air; by and by some advantage as to quality, produce, or time, might be procured, which would give rise to their more general introduction towards the concluding part of the process, in order more $\mathrm{c}$ 'mpletely to separate the iron from its oxide and from the earths, and to unite the masses more firmly together, to withstand the shock of the hammer. The partial application of the bellows, however, was widely different from its more general application to the purposes of smelting. In the old process the pieces of ore were matured by a long period of cementation; but no perfect fusion or separation took place. The metallic particles coalesced, and part of the oxides and earths were discharged in consequence of their being fusible

* Communicated by the Author.

Vol. 60. No. 294. Oct. 1822. 
at a lower temperature; but the greater part of the expulsion, on which the purity and quality of the iron depended, took place under the hammer. By the introduction of smelting, a fusion comparatively perfect was obtained, and the charge of the furnace in a short time resolved into fluid scoria and metal. The basis of the operation, therefore, was completely changed; and it became the principal operation of the smith to remove the crudeness imparted by fusion to the iron, by such means and processes as occurred tohim, or as experience pointed out, and to which has since been given the term of refining.

As this part of the operation would be the first and earliest attempt at the refining-furnace, so it is probable that the resulting bar-iron would be found in point of quality, toughness, and purity of fracture, superior to the iron obtained in the airfurnace. A conclusion would be formed by the smith in favour of the general use of bellows; and at this juncture those trials and experiments would commence, which terminated in the general introduction of the blast-bloomery, a furnace that for many ages maintained itself exclusively for the manufacture of iron over every iron-making country in Europe.

'The furnace was constructed of stone capable of standing a high temperature, about two feet in height, and from a foot and in half to two feet square within, according to the power of the bellows: on the lower end of the furnace were two openings, one large in the front, the other of smaller dimensions behind, or on one side, for the insertion of the blast pipe. When the furnace was properly filled and heated with charcoal, a certain measure of ore and charcoal was added, according to the size of the bloom or blooms wished to be obtained, and which could be conveniently removed by the front opening in the furnace. The bellows were then urged. The charge melted, and the iron in the state of a crude steel, more or less separated from the ores, rested in an imperfectly fluid state upon the furnace bottom. Another operation therefore followed: After adding a measure of charcoal to cover effectually the surface of the metal, the nose of the bellows' pipe was inclined towards its surface, and part of the vitrid matter formed during the fusion allowed to run out. After blowing on the metal a certain length of time, it gradually by the burning out of the carbon became thick and lumpy. Iron bars were introduced at the front opening to break up the mass and to expose the lumps to the action of the blast, as is at present done in the charcoal refinery. When the operation was deemed complete, and the iron enough refined, the burning mass was removed through the front opening, either to the anvil or a large stone, and there beat into form. 
In this improved state of the process, two distinct species of cinders, or scoria, were produced. First, in the smelting of the ores, which from the imperfect reduction contained about 20 per cent. of oxide of iron mixed with the earthy matter of the ore;-secondly, in the refining part of the operation, where the scoria produced contained from 70 to 80 per cent. of oxide of iron mixed with the earthy matter of the ores, and the vitrid waste of the interior of the furnace.

Abstractedly considered, the operation of the blast-bloomery furnace must be pronounced strictly philosophical, whereby was effected the double purpose of smelting and refining, in both of which large quantities of iron originally contained in the ore were lost. The operation itself, when well performed, was the mean between two extremes, which it must have been the interest and the anxiety of the snith to avoid. If the furnace was charged with too small a proportion of charcoal, or too large a relative quantity of iron ore, several evils would follow; - a lack of heat, a want of proper carbonation, and an imperfect fusion or separation; masses of ore would pass the blast unmelted, and mingle with the crude iron that had been reduced from the smaller masses of ore, presenting to the operation of refining an imperfect and unhomogeneous surface. On the contrary, an extra dose of charcoal, or a lessened relative proportion of ore, would lead to consequences the reverse of the former; under a higher temperature, an extra dose of carbon would unite with the iron, which would be precipitated on the bottom in a state too fluid for the usual length of time appropriated to the refinement. To divest the iron of its extra dose of carbon, the bellows would be directed upon its surface for a much longer time before it began to conlesce, or was tough enough to break up with the bars, a larger quantity of cinder would be discharged, and less of metal proportionate to the length of refinement.

When the operation was performed in the most perfect manner, not more than one-half of the iron was obtained from the ores. This gave rise to an immense accumulation of scoria, which in after ages, and subsequently to the invention of the blast-furnace, became a source of great wealth to the proprietor of land, who occasionally under ancient forests, or the deepest soils, discovered large quantities of these cinders, which were eagerly purchased by the smelters and used in the blast furnace, in mixture with ores, for the production of cast-iron.

Notwithstanding the small produce which in former times was obtained from the ores smelted in the bloomery furnace with charcoal as fucl, the late Colonel Fullarton attempted to I i 2 introduce 
introduce the furnace, about five-and-twenty years ago, for the purpose of making bar-iron with coke and rich ironstones or ores. The blast-bloomery he employed was 3 feet in height, and from $2 \frac{1}{2}$ to $2 \frac{3}{4}$ feet in width ; like the old charcoal bloomery, it had an opening in front, and a blast-hole about nine inches from the bottom which admitted a pipe of $1 \frac{1}{\mathrm{~s}}$ inch in diameter. The furnace was filled with coke, gradually heated, and the blast introduced; then in small alternate portions were charged, four cwt. of ironstone, and in the whole 10 bushels of coke, containing about 700 pounds of fuel, or nearly the produce of one ton of raw pit-coal. In less than one hour the whole charge was smelted, the cincler was then tapped from the surface of the iron, upon which the blast-pipe was now inclined as in the old furnaces. After a period of six hours, the lump was deemed sufficiently malleablized; the fiont of the furnace was broken down, and the mass carried to the forge hammer. In this way about $130 \mathrm{lbs}$ of bar iron were obtained from 4 cwt. of Lancashire ore, or the same quantity of roasted ironstone of a very rich quality.

The Lancashire ore contained about $290 \mathrm{lbs}$ of iron; so of this quantity $130 \mathrm{lbs}$ only were recovered, or equal to 4.5 per cent. of the iron, and about 30 instead of 65 from the ore.

The ironstone was of a peculiar nature, a combination of iron and bituminous matter; so that, when roasted, the dissipation of the inflammable matter left a pure oxide of iron in thin beds or laminæ, which in the crucible yielded upwards of 70 per cent.; so that not 40 per cent. of the iron only was revived; and if the yield in iron is deducted from the ironstone in its raw state, two tons of which yielded about one ton of iron, the produce was not more than 20 per cent.

The whole operation, from filling to falling the furnace, took eight hours. The bloom in drawing out lost about eighteen pounds of iron; so that at the conclusion of the experiment not more than one hundred weight of finished bar-iron was obtained. A calculation founded upon this result, would give for one ton of bar-iron twenty tons of raw coal, and five tons of Lancashire ore; or; when used in preference, ten tons of ironstone, besides an immense increase of labour.

To accidental enlargement of the blast-bloomery, we most likely owe the discovery of cast-iron. With a view of improving the process, some enterprising smith may have added to the height of his furnace, and accidentally or by design enlarged the dose of charcoal. In tapping the furnace previous to refinement, he might be struck with a difference in the colour of the scoria, and the increased fluidity of the iron which might 
might accompany it. These masses would be compared with former accidental productions, and the difference observed: at first they would most likely be returned into the bloomery to increase the general produce, but in time become the subject of a separate experiment. It would on trial be found, that they would melt in the common smithy, and by being blown upon in a manner similar to the refining part of the bloomery operation, pass into the state of malleable iron. This would first suggest the idea of a separate furnace and operation for the refinement of iron. The permanent enlargenent of the bloomery furnace would ensue. The ores, by a greater descent and longer contact with the fuel, would be more thoroughly cemented. The iron would take up carbon in quantity, fusibility proportionally increase, and cast-iron in all its varieties, from the white conchoidal fracture to the large-grained deep grey, be obtained.

From this period, the making of iron would divide itself into two branches, - the furnace and forge departments; and, like other judicious divisions of labour, would give new spirit and enterprise to the art: in time foot-blasts and hand-blasts, or bellows, would be abandoned, and a more effectual moving power found on the banks of the adjacent streams. Waterwheels, giving motion to bellows and hammers, would succeed the crude and infantine efforts of a ruder age; and these in their turn would give way to other improvements, in a riper age, much more powerful and striking.

XLVII. On the Application of Magnetism as a Mcasure of Electricity. By the Rev. J. Cumming, M.A. F.R.S. M.G.S. Professor of Chemistry in the University of Cambridge. *

\section{T}

$\mathrm{T}_{\mathrm{HE}}$ methods hitherto in use for ascertaining the quantity and intensity of the electricity produced either by friction or by galvanic action, are (independently of the shock on the animal frame, which obviously affords no definite measure, ) derived from its power in decomposing water, or fusing metallic wires. When the electricity is either small in quantity, or of low intensity, there are considerable difficulties in the practical application of either of these methods.

The fusion of platina wire by the elementary battery of Dr. Wollaston, proves that the quantity of electricity developed by very minute metallic surfaces is considerable; yet, exclusively of the difficulty in soldering wires that are barely visible, it is almost impossible to ascertain their length with any pre-

* From the Cambrige Philosophical Transactions for 18\%?, Part II. cision. 